\title{
C-HETEROCHROMATIN CONTENT OF SUPERNUMERARY CHROMOSOME SEGMENTS OF GRASSHOPPERS: DETECTION OF AN EUCHROMATIC EXTRA SEGMENT
}

\author{
J. P. M. CAMACHO, E. VISERAS, J. NAVAS, AND J. CABRERO \\ Departamento de Genética, Facultad de Ciencias, Universidad de Granada, Granada, Spain \\ Received 2.xii.83
}

\section{SUMMARY}

\begin{abstract}
The response of 11 supernumerary segments to C-banding has been compared in six species of grasshoppers. A unique euchromatic supernumerary segment was present in the five populations of Omocestus bolivari analysed. It appears negatively heteropycnotic during the first prophase of meiosis and does not C-band. This euchromatic segment is distally located in the $\mathbf{M}_{6}$ chromosome and in every case was present in a heterozygous condition. It does not associate with the telomere of its unsegmented homologue and, consequently, the unequal $M_{6}$ bivalents always segregate equationally for the extra segment in the first meiotic division. This euchromatic segment does not influence mean cell chiasma frequency but does influence chiasma position in the $\mathrm{M}_{6}$ bivalents carrying it. Four additional types of heterochromatic supernumerary chromosome segments may be distinguished in grasshoppers by $\mathrm{C}$-banding: a) those darkly C-banded, b) those partly darkly C-banded, c) those lightly C-banded and d) those which do not C-band. All five types of segment appear to affect chiasma distribution in heterozygous monochiasmate bivalents but only those heterochromatic segments that do not C-band influence mean cell chiasma frequency.
\end{abstract}

\section{INTRODUCTION}

Grasshopper populations are frequently polymorphic for heterochromatic supernumerary chromosome segments which show positive heteropycnosis during the first prophase of meiosis. An adaptive role for such extra segments may be based on their effects on the distribution and frequency of chiasmata and the consequent influence these effects have on the regulation of recombination (John, 1981). The heterochromatic nature of such supernumerary chromosome segments may be responsible for these effects. In view of the great heterogeneity of heterochromatin in the standard complement (Rocchi, 1982), it is of interest to discover whether the supernumerary heterochromatin is also heterogeneous and, if so, to search for a possible relation between the heterochromatic nature of each type of supernumerary segment and its effects on recombination. To date four types of extra segments have been detected in grasshoppers. John and King (1977) found that while the majority of heterochromatic supernumerary segments in Cryptobothrus chrysophorus consist of uniformly darkly C-banded material, some show a much lighter staining when C-banded, and others may consist of material which does not C-band at all. Additionally, Gosálvez and López-Fernández (1981) described an extra heterochromatic segment in Gomphocerus sibiricus which C-bands only in part.

In this paper we review the existing information about the heterochromatic nature of supernumerary segments in grasshoppers and analyse 11 such segments in six grasshopper species by the C-banding technique. We 
describe an exceptional euchromatic supernumerary segment in addition to the four different types of heterochromatic supernumerary segment already recognised, and compare their effects on chiasma frequency and chiasma distribution.

\section{Materials AND METHOdS}

Adults and embryos of six grasshopper species (Omocestus bolivari, $O$. raymondi, Chorthippus brunneus, Ch. parallelus, Oedipoda fuscocincta and Calliptamus barbarus barbarus) were collected in the South of the Iberian Peninsula. Adult individuals were analysed cytologically by the methods described in Camacho and Cabrero (1982). The embryos were studied cytologically following the technique described by Webb et al. (1978). C-banding was carried out as follows: air dried squashes of adult testes and embryos were treated with $0.2 \mathrm{~N} \mathrm{HCl}$ at $20^{\circ} \mathrm{C}$, immersed in saturated $\mathrm{Ba}(\mathrm{OH})_{2}$ at $60^{\circ} \mathrm{C}$ for $2-5 \mathrm{~min}$ and then in $2 \times \mathrm{SSC}$ at $60^{\circ} \mathrm{C}$ for $1 \mathrm{~h}$. Staining with 10 per cent Giemsa for about $5 \mathrm{~min}$ was followed by mounting in DEPEX.

\section{REsults}

Five populations of Omocestus bolivari from the Sierra Nevada (Spain) have been analysed in this report and in all of them we have found a supernumerary chromosome segment distally located in the megameric, and predominantly heterochromatic, $\mathbf{M}_{6}$ chromosome. This extra segment is euchromatic, does not show positive heteropycnosis during the first prophase of meiosis (plate 1) and does not exhibit C-banding (plates 2-4). This extra segment is relatively infrequent in these populations and only heterozygous individuals were found: 1 male out of 40 in Las Sabinas population ( 2.5 per cent), 1 out of 18 in Campos de Otero ( 5.56 per cent), 2 out of 76 in Albergue Universitario (2.63 per cent), 1 out of 22 in Alto del Chorrillo ( 4.55 per cent) and 1 out of 55 in La Alberquilla ( 1.82 per cent).

We have examined the influence of this extra segment on chiasma formation at two levels: 1) on mean cell chiasma frequency and 2) on chiasma distribution in the $M_{6}$ bivalent. With respect to the first of these we find that in the Albergue Universitario population the two heterozygous for the $M_{6}$ segment showed a mean cell chiasma frequency $(\bar{x}=16.00)$ similar to that of 74 standard males $(\bar{x}=15.73)(t=0.83, P=0.41)$. Chiasma distribution in the $\mathbf{M}_{6}$ bivalent has also been compared in male diplotene cells with and without a segment. In standard males both mono and bi-chiasmate bivalents were present. In the former, the single chiasma was invariably located in a short distal euchromatic zone in the otherwise heterochromatic bivalent ( 151 cells). When there were two chiasmata they were always distally and proximally located (19 cells). In heterozygous males the $\mathbf{M}_{6}$ bivalent always contained a single chiasma which was located proximally in 20 cells ( 22 per cent), interstitially in 64 cells ( 72 per cent) and distally in 4 cells ( 5 per cent). A contingency $\chi^{2}$ test indicates that in heterozygous males there is a significant reduction in the number of chiasmata located distally $\left(\chi_{(1)}^{2}=183.85, P<0.001\right)$. Thus the presence of the euchromatic segment is associated with a movement of chiasmata interstitially and proximally (see fig. 1). The extra euchromatic segment was 

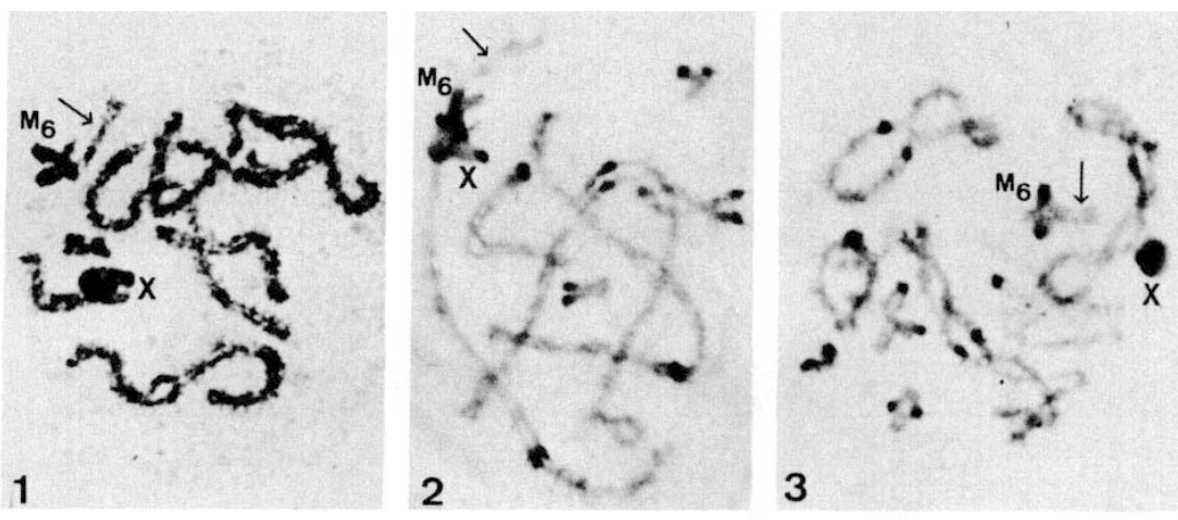

3
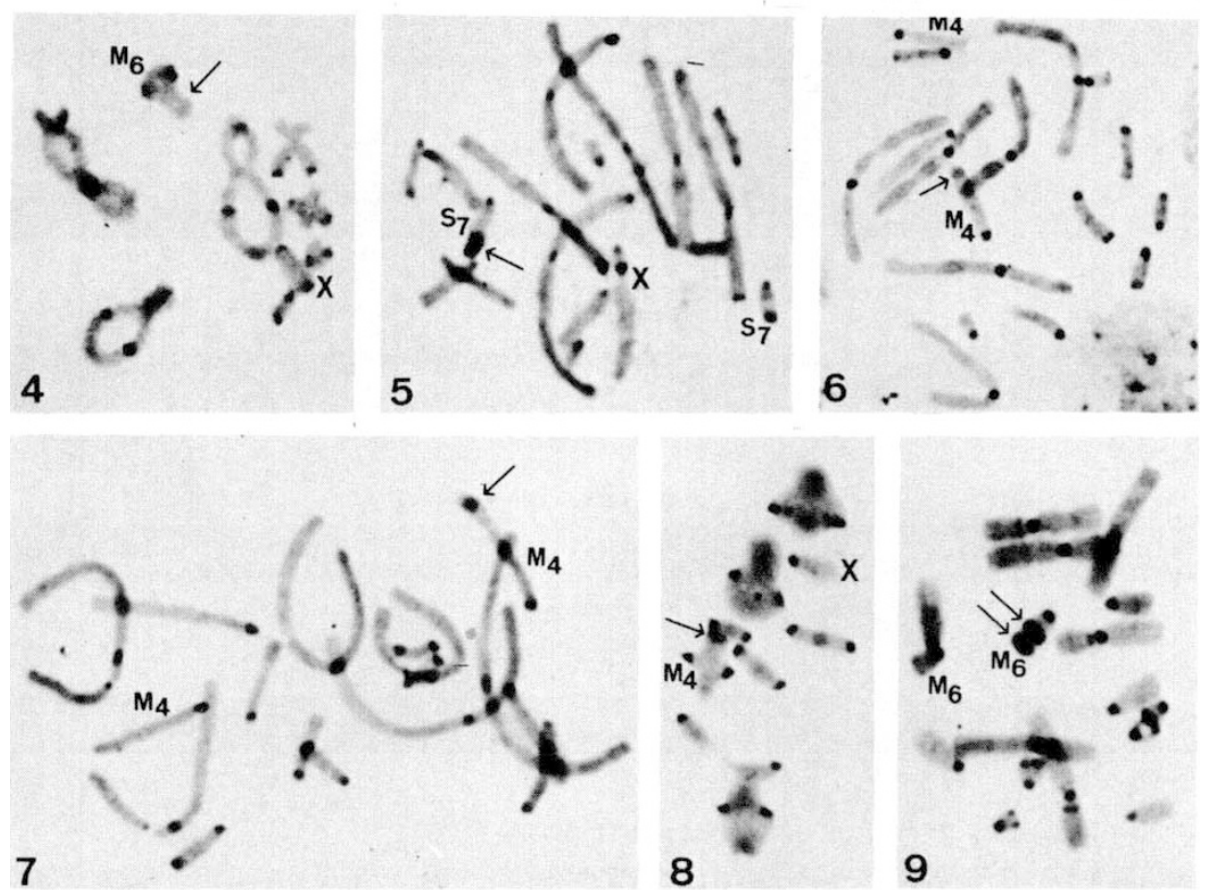

Plates 1-9. Supernumerary chromosome segments in Omocestus bolivari (1-4), O. raymondi (5) and Chorthippus brunneus (6-9). Plate 1. Orcein-stained pachytene cell of $O$. bolivari showing the negative heteropycnosis of the distally located extra segment (arrow) in the $M_{6}$ chromosome. Plates 2-4. C-banded pachytene (2) and diplotene (3 and 4) cells of the same species. Note that the extra segment (arrow) does not C-band. Plate 5. Mitotic metaphase from an embryo of $O$. raymondi which was heterozygous for a distally located and darkly C-banded extra segment in the $S_{7}$ chromosome (arrow). Plates 6 and 7. Embryonic mitotic metaphase cells of $C h$. brunneus showing an interstitially located extra segment in one of both $\mathrm{M}_{4}$ chromosomes. This segment is lightly C-banded (arrow). Plate 8. The lightly $\mathrm{C}$-banded segment in the $\mathrm{M}_{4}$ chromosome of $\mathrm{Ch}$. brunneus during metaphase I of meiosis. Plate 9. Mitotic metaphase cell from an embryo of $C h$. brunneus which was heterozygous for two darkly $\mathrm{C}$-banded extra segments in the $\mathbf{M}_{6}$ chromosome. 


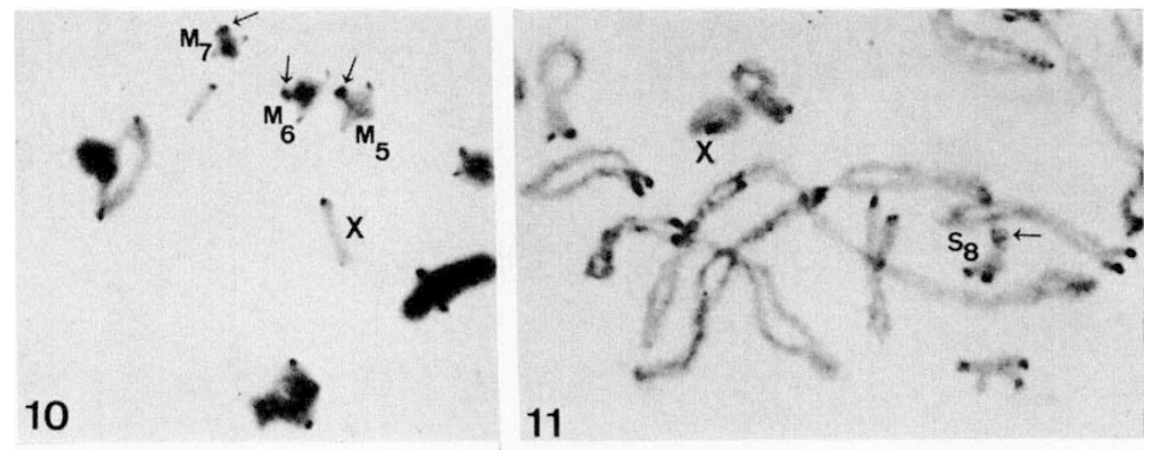

12
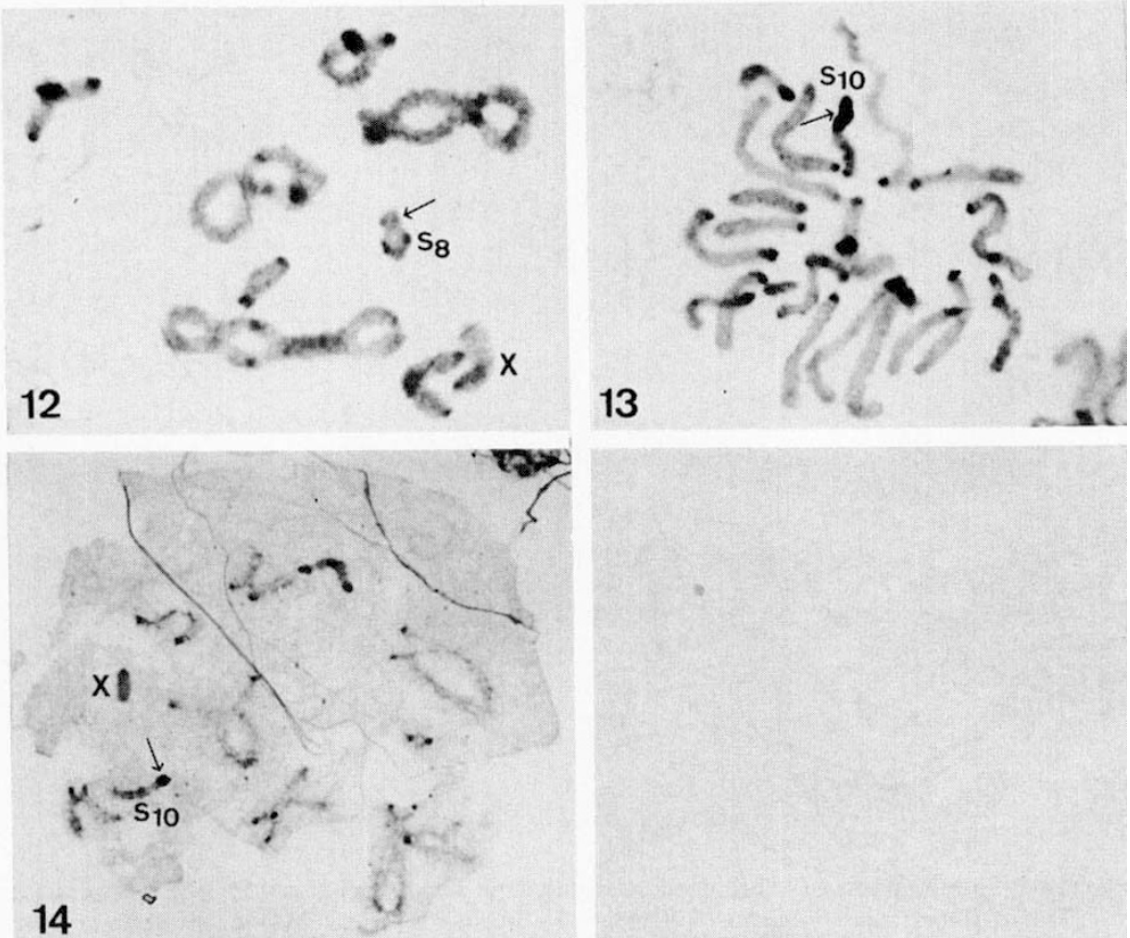

Plates 10-14. Supernumerary chromosome segments in Chorthippus parallelus (10-12) and Oedipoda fuscocincta (13 and 14). Plate 10. Metaphase I cell from a male of $C h$. parallelus which was heterozygous for distally located and darkly C-banded extra segments in $\mathbf{M}_{5}$, $\mathbf{M}_{6}$ and $\mathrm{M}_{7}$ chromosomes (arrows). Plates 11 and 12. Early diplotene (11) and diakinesis (12) cells from a male of $\mathrm{Ch}$. parallelus which was heterozygous for a distally located extra segment in the $\mathbf{S}_{8}$ chromosome (arrows). Note that this segment shows positively heteropycnotic but does not C-band. Plates 13 and 14. Spermatogonial mitotic metaphase (13) and diplotene cell (14) from a male of $O$. fuscocincta which was heterozygous for a distally located and darkly C-banded extra segment in the $\mathbf{S}_{10}$ chromosome. 

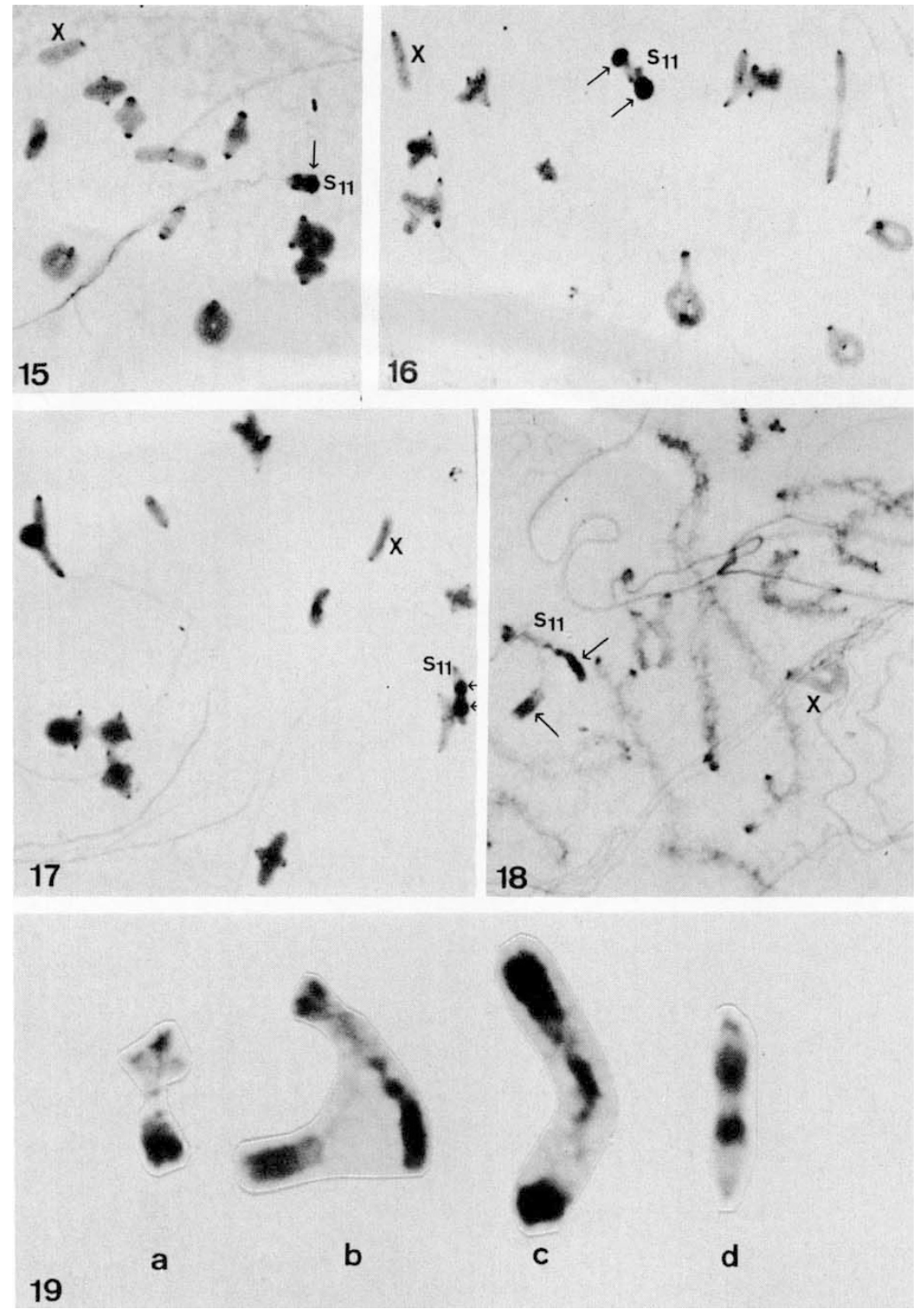

PLATES 15-19. Extra segment (arrow) in the $S_{11}$ chromosome of Calliptamus barbarus barbarus. Plate 15. Metaphase I cell from a heterozygous male. The extra segment is not entirely $C$-banded because the unsegmented homologue is shorter than the not-C-banded zone in the segmented one. So, part of this not-C-banding zone must belong to the extra segment. Plates 16 and 17. Metaphase I cells from a homozygous male showing the different size of the darkly C-banded zone between both segments. In Plate 17 note the association between the distal zone of both segments which does not C-band. Plate 18. Early diplotene cell from a homozygous male showing the $\mathrm{C}$-banding pattern of both segments. The segment sited to the left of the figure is similar to those observed in heterozygous males and that to the right was only observed in homozygous males. Plate 19. Individual enlarged bivalents from pachytene-diplotene $(a-c)$ and metaphase I (d) cells to show the partially darkly $\mathrm{C}$-banded extra segments in heterozygous males (a), the differences in C-banding pattern and coiling properties between both segments in homozygous males (b, $c$ and d), and the association between the segments by their distal not-C-banded region (d). 


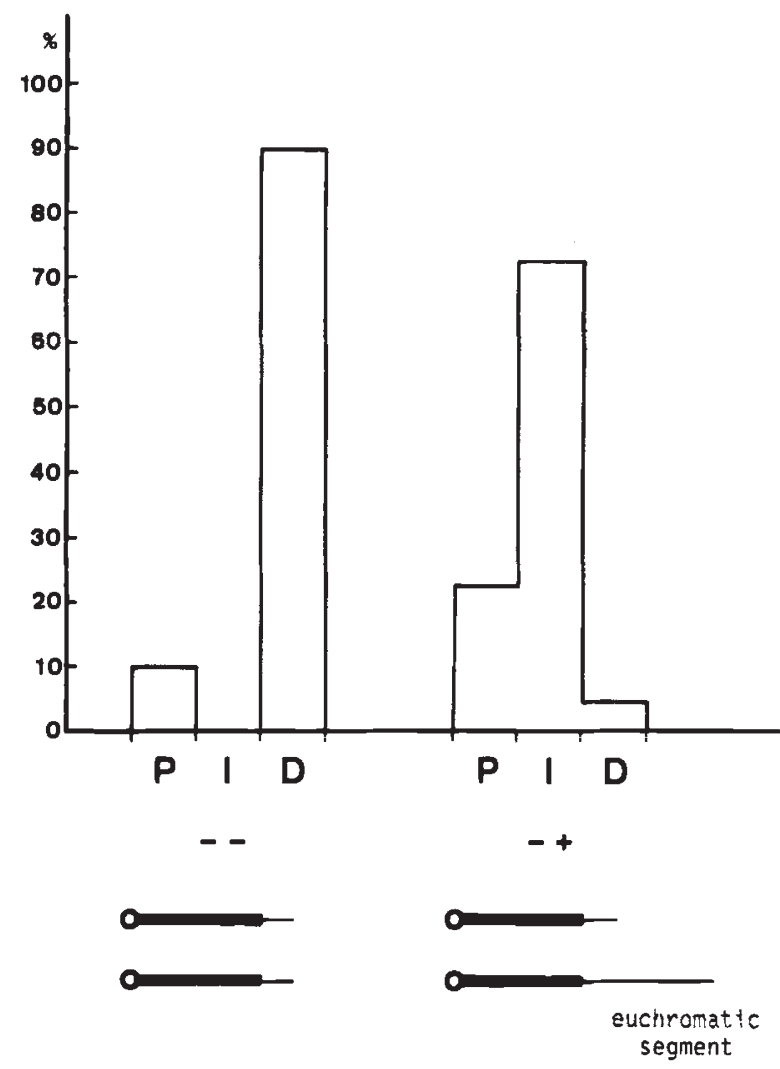

FIG. 1. Effects of the extra euchromatic segment in the megameric $\mathrm{M}_{6}$ chromosome of Omocestus bolivari on chiasma distribution in this bivalent. For scoring chiasma distribution the $\mathrm{M}_{6}$ bivalent was divided into three zones: proximal (P), interstitial (I) and distal (D). While the $P$ and $I$ sites were positively heteropycnotic during the first meiotic prophase, $D$ was negatively heteropycnotic, like the extra segment. The scores were made in 170 diplotene cells from standard males (- ) and 88 diplotene cells from males heterozygous for the euchromatic segment $(-+)$. Note the decrease in the frequence of distal chiasma in heterozygous males by the presence of the distally located extra euchromatic segment.

never found associated with the telomere of its unsegmented homologue despite the fact that this region too is euchromatic. Consequently in all 57 second metaphase and anaphase cells analysed only chromosomes with unequal chromatids were observed which indicates that, as expected, the unequal $\mathrm{M}_{6}$ bivalents always divide equationally at the first meiotic division.

In Omocestus raymondi we have previously reported the presence of a supernumerary chromosome segment in the $\mathrm{S}_{7}$ chromosome (Camacho and Cabrero, 1982). When analysed by the C-banding technique this segment shows dark C-banding (plate 5).

In Chorthippus brunneus we have observed extra segments in all members of the complement (Cabrero, unpublished data) though in this report we will refer only to those present in the $\mathrm{M}_{4}$ and $\mathrm{M}_{6}$ chromosomes. The extra segment in the $\mathrm{M}_{4}$ chromosome is nearly distal and is more lightly C-banded than either the centric segment of the $\mathrm{M}_{4}$ or the other $\mathrm{C}$-banded regions 
(plates 6-8). Two types of $M_{6}$ chromosomes are also found. The standard type shows a strong procentric $\mathrm{C}$-band and a faint telomeric $\mathrm{C}$-band, while the segmented type carries two darkly C-banded extra segments, one in a distal position and the other in an interstitial position (plate 9).

Supernumerary chromosome segments present distally on the $M_{6}, M_{7}$ and $\mathrm{S}_{8}$ chromosomes of Chorthippus parallelus have been extensively studied in British and French populations, prior to the introduction of C-banding (John and Hewitt, 1966, 1969; Hewitt and John, 1968, 1970; Westerman, 1969, 1970). In this report we have analysed a Spanish population, also collected in the Sierra Nevada, in which we have found supernumerary segments distally located in chromosomes $\mathbf{M}_{5}, \mathbf{M}_{6}, \mathbf{M}_{7}$ and $\mathbf{S}_{8}$. On the basis of size, we think that the $S_{8}$ segment in our population may be the same as that found in British and French populations, but those in the $\mathbf{M}_{6}$ and $\mathbf{M}_{7}$ may well be different. C-banding reveals that in Spanish specimens the extra segments on the $M_{5}, M_{6}$ and $M_{7}$ chromosomes all show dark C-banding (plate 10 ) whereas that in the $S_{8}$ does not C-band (plates 11 and 12).

In Oedipoda fuscocincta and Calliptamus barbarus barbarus we have previously reported the presence of distally located supernumerary chromosome segments in the $S_{10}$ and $S_{11}$ chromosomes (Camacho and Cabrero, 1982). The extra segment in the $S_{10}$ chromosome of $O$. fuscocincta shows dark C-banding (plates 13 and 14) whereas that in the $S_{11}$ of C.b. barbarus appears darkly $\mathrm{C}$-banded only in its mid zone and carries proximal and distal zones which do not C-band (plates 15-19). The non C-banded distal zone of the extra heterochromatic segment may take part in persistent associations with the euchromatic telomere of the unsegmented homologue (in heterozygous males) leading to reductional division of unequal $S_{11}$ bivalents (Camacho and Cabrero, 1982). Furthermore, in males homozygous for the extra segment, the associations between the non C-banded distal zones of both segments may persist till metaphase I (plates 17 and 19d). On the other hand, in the two males homozygous for the extra segment in the $S_{11}$ chromosome both segments seemed to be different: one appeared partly C-banded (like those in the heterozygous males) while the other was also C-banded in its proximal zone (plates 16-19). The existence of a single class of segment in the 10 heterozygous males suggests that a regulatory mechanism may operate in the homozygous males which affects the coiling properties of one of the two segments.

\section{Discussion}

The supernumerary segment in the $\mathrm{M}_{6}$ chromosome of Omocestus bolivari is euchromatic in character as judged both by its negative heteropycnosis during first meiotic prophase and its negative reaction to $\mathrm{C}$-banding. This is the first euchromatic supernumerary segment found in grasshoppers. All previously reported segments in these animals show at least positive heteropycnosis during first meiotic prophase, which is the primary condition for defining heterochromatin at meiosis (Heitz, 1928). The existence of this extra euchromatic segment has led us to reconsider the more general question of the origin of supernumerary segments. Two hypotheses have been put forward to explain their origin: 1) the duplication of existing autosomal material (Shaw, 1970; John, 1973; Hewitt, 1979) and 2) translocation from 
other autosomes or from B-chromosomes (White, 1973). One might expect this segment to be heterochromatinised, as has been observed for extra $\mathbf{M}_{4}$ autosomes in polysomic individuals of Chorthippus parallelus (Hewitt and John, 1968, 1970) and O. bolivari (Camacho et al., 1981). Added to this, the extra euchromatic segment shows no homology by association with any element of the standard complement. The extra euchromatic segment of $O$. bolivari has no homology even with the euchromatic distal zone in the unsegmented $\mathbf{M}_{6}$ chromosome, since associations between euchromatic regions leading to reductional segregation of unequal $\mathbf{M}_{6}$ bivalents were never observed. Bearing these facts in mind, it is difficult to be confident about the origin of this supernumerary euchromatic segment. If we assume an origin of the segment involving a repetition of chromosome material (duplication or translocation), it is surprising that the coiling properties of the repeated material have not been modified by heterochromatinisation of the extra segment.

The extra euchromatic segment is present at a similar low frequency in all five populations analysed and these are, unquestionably, fully representative of the complete distribution of $O$. bolivari, an endemic species which lives only in the Sierra Nevada at altitudes ranging from 1750 to $2900 \mathrm{~m}$ (Pascual, 1978). Three of these populations were collected on the North side at Las Sabinas $(2100 \mathrm{~m})$, Campos de Otero $(2200 \mathrm{~m})$ and Albergue Universitario $(2500 \mathrm{~m})$, while the other two were collected on the South side at Alto del Chorrillo $(2700 \mathrm{~m})$ and La Alberquilla $(2400 \mathrm{~m})$. On both sides the populations sampled were separated by a distance of several $\mathrm{km}$. Given the low vagility of these grasshoppers there seems little doubt that the populations were isolated from one another. This, in turn, implies that the euchromatic segment must have been in existence prior to the current postglacial isolation.

The other extra segments described in this paper could well have arisen by repetition of chromosome material, most probably by a duplication process. While that of Omocestus raymondi may derive from the duplication of heterochromatic material (since the standard $\mathrm{S}_{7}$ chromosome shows a telomeric $\mathrm{C}$-band), others like those of Chorthippus parallelus $\left(\mathrm{S}_{8}\right.$ chromosome), Oedipoda fuscocincta ( $\mathrm{S}_{10}$ chromosome) and Calliptamus barbarus barbarus ( $\mathrm{S}_{11}$ chromosome) may have originated from a duplication of euchromatic material (since the standard chromosomes lack telomeric Cbands) with a subsequent heterochromatinisation of the repeated segment. In one case the extra segment does not C-band ( $\mathrm{Ch}$. parallelus), in another it is positively C-banded (O. fuscocincta) and in a third it is partly positively C-banded (C.b. barbarus). Thus supernumerary segments which have presumably originated from a similar process (duplication) and appear heterchromatic on the basis of their positive heteropycnosis may still show very different reactions to C-banding.

Table 1 shows the range of types of supernumerary segments in grasshoppers on the basis of their $\mathrm{C}$-heterochromatin content.

Such a variety segment types which differ in their reactions to C-banding, demonstrate that, like the heterochromatin of the standard complement (Rocchi, 1982), supernumerary heterochromatin is also heterogeneous. Moreover this heterogeneity of extra heterochromatin needs to be taken into consideration before generalising the results obtained in investigations involving supernumerary chromosome segments. 


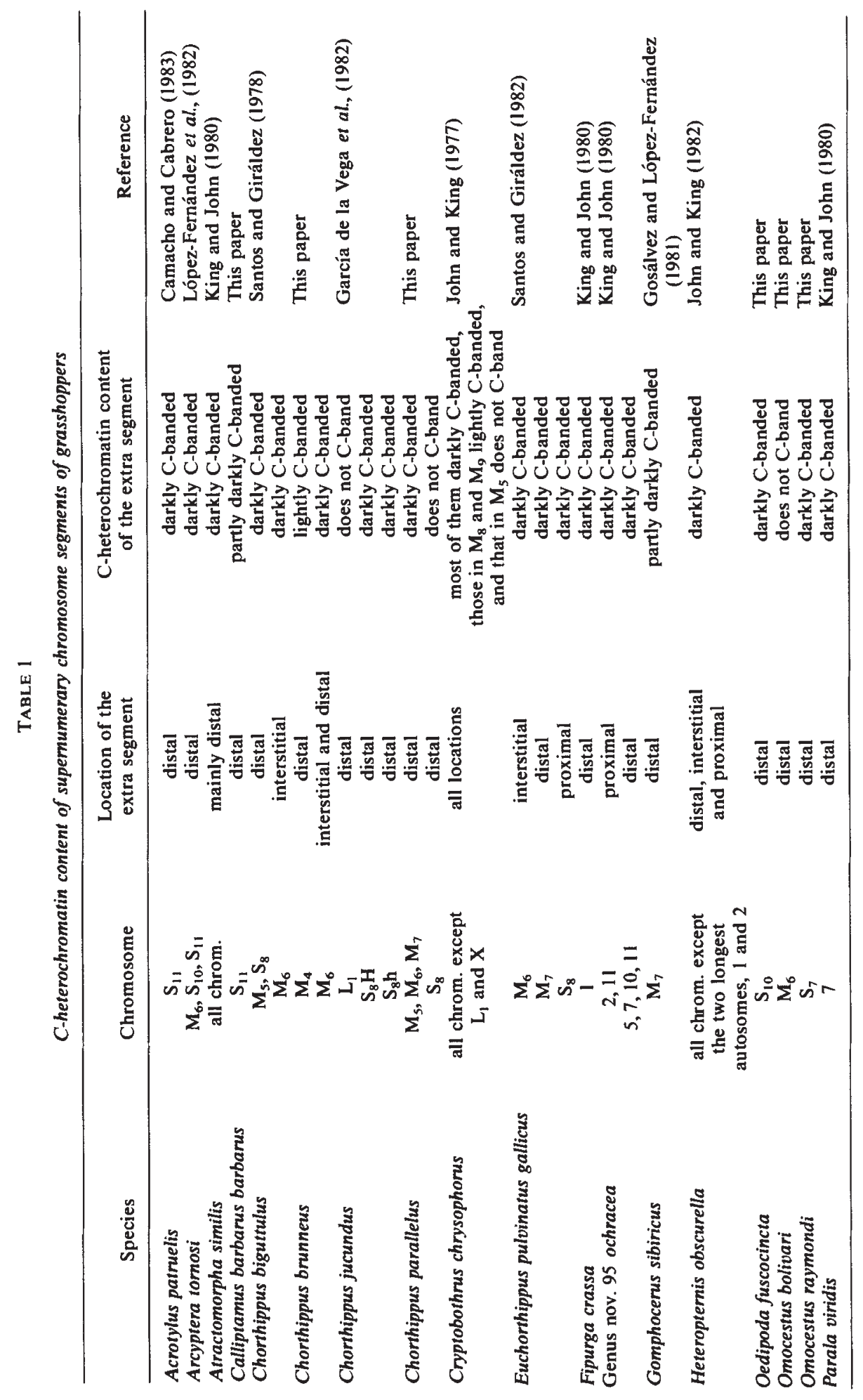




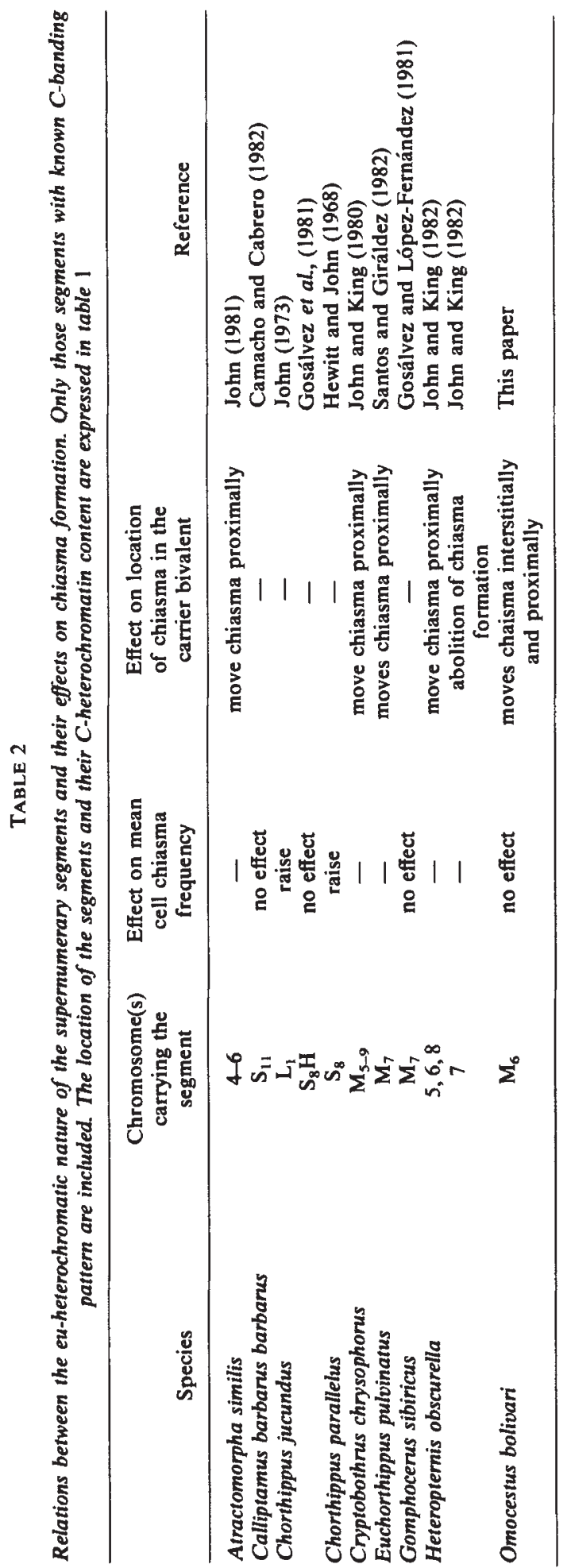


As John and King (1980) demonstrate, distally located supernumerary segments may participate in het-het or het-eu terminal associations at meiosis which lead to their reductional division at first anaphase. In the case of the distal extra segment in the $S_{11}$ chromosome of Calliptamus barbarus palaestinensis (which is presumably the same as we have observed in C.b. barbarus), such reductional divisions were interpreted by Nur (1961) to imply the existence of a minute euchromatic zone located beyond the extra segment which participate in chiasmate associations with the telomere of the unsegmented homologue. We have been unable to identify such a zone in C.b. barbarus and the occasional reductional division observed in this subspecies is more easily explained by a persistent non-chiasmate association between the distal zone of the segment (which is heteropycnotic and does not C-band) and the euchromatic end of the unsegmented homologue, as has been suggested by John and King (1982).

The heterogeneity of extra heterochromatic segments needs also to be considered in examining their effects on chiasma formation viz., effects on total cell chiasma frequency and effects on chiasma location in those bivalents which carry the extra segments. From the available data (table 2) it can be deduced that heterochromatic segments which do not C-band (like those of Chorthippus parallelus and Ch.jucundus) raise cell chiasma frequency. On the other hand, neither the partly darkly C-banded segments (like those of Gomphocerus sibiricus and Calliptamus barbarus barbarus) nor the darkly $\mathrm{C}$-banded $\mathrm{S}_{8}$ segment of Chorthippus jucundus do so and the same is true for the extra euchromatic segment of Omocestus bolivari.

As far as chiasma distribution is concerned, in all cases in which this has been studied (table 2) the distal extra heterochromatic segments which C-band darkly (like those of Euchorthippus pulvinatus, Heteropternis obscurella, Cryptobothrus chrysophorus and Atractomorpha similis) appear to move chiasmata to more proximal zones in carrier bivalents as too does the distal extra euchromatic segment of Omocestus bolivari (fig. 1). The proximally sited and darkly C-banded segment in chromosome 7 of Heteropternis obscurella, on the other hand, abolishes proximal chiasma formation.

In conclusion, the effect that supernumerary segments have on cell chiasma frequency appear to depend on the type of heterochromatin they contain, whereas their effects on chiasma location in the bivalent which carries them does not.

\section{REFERENCES}

CAMACHO, J. P. M. AND CABRERO, J. 1982. Supernumerary segments in five species of grasshoppers (Orthoptera: Acridoidea). Genetica, 59, 113-117.

CAMACHO, J. P. M. AND CABRERO, J. 1983. Karyological differences between two species of grasshopper genus Acrotylus (Acrididae: Oedipodinae). Caryologia, 36, 121-127.

CAMACHO, J. P. M., DIAZ DE LA GUARDIA, R. AND RUIZ REJON, M. 1981. Polysomy and supernumerary isochromosomes in the grasshopper Omocestus bolivari (Chopard). Heredity, 46, 123-126.

garcia de la Vega, C., lopez-Fernandez, C., Gosalvez, J. AND Rufas, J. S. 1982. Cytogenetic studies on Chorthippus jucundus (Fisch.) (Orthoptera). II. Heterochromatin variation and NOR localization. Cytobios, 34, 7-14.

GosalveZ, J., GaRCia DE la VEGa, C., lopez-FERNANDEZ, C. AND RUFAS, J. S. 1981. Cytogenetic studies on Chorthippus jucundus (Fisch.) (Orthoptera: Acrididae). I. Heterochromatic segments in Spanish wild populations. Brotéria-Genética (Lisboa), II (LXXVII), 41-50. 
GOSALVEZ, J. AND LOPEZ-FER NANDEZ, C. 1981. Extra heterochromatin in natural populations of Gomphocerus sibiricus (Orthoptera: Acrididae). Genetica, 56, 197-204.

HEITZ, E. 1928. Das Heterochromatin der Moose I. Pringsheims Jb. wiss. Bot., 69, 762-818.

HEWITT, G. M. 1979. Grasshoppers and crickets. Animal Cytogenet, vol. 3: Insecta I Orthoptera. Berlin-Stuttgart: Gebrüder Borntraeger.

HEWITT, G. M. AND JOHN, B. 1968. Parallel polymorphism for supernumerary segments in Chorthippus parallelus (Zetterstedt) I. British populations. Chromosoma, 25, 319-342.

HEWITT, G. M. AND JOHN, B. 1970. Parallel polymorphism for supernumerary segments in Chorthippus parallelus (Zetterstedt) IV. Ashurst re-visited. Chromosoma, 31, 198-206.

JOHN, B. 1973. The cytogenetic system of grasshoppers and locusts II. The origin and evolution of supernumerary segments. Chromosoma, 44, 123-146.

JOHN, B. 1981. Heterochromatin variation in natural populations. Chromosomes today, 7 , 128-137.

JOHN, B. AND HEWITT, G. M. 1966. A polymorphism for heterochromatic supernumerary segments in Chorthippus parallelus. Chromosoma, 18, 254-271.

JOHN, B. AND HEWITT, G. M. 1969. Parallel polymorphism for supernumerary segments in Chorthippus parallelus (Zetterstedt) III. The Ashurst population. Chromosoma, 28, 73-84.

JOHN, B. AND KING, M. 1977. Heterochromatin variation in Cryptobothrus chrysophorus II. Patterns of C-banding. Chromosoma, 65, 59-79.

JOHN, B. AND KING, M. 1980. Heterochromatin variation in Cryptobothrus chrysophorus III. Synthetic hybrids. Chromosoma, 78, 165-186.

JOHN, B. AND KING, M. 1982. Meiotic effects of supernumerary heteroch romatin in Heteropternis obscurella. Chromosoma, 85, 39-65.

KING, M. AND JOHN, B. 1980. Regularities and restrictions governing C-band variation in acridoid grasshoppers. Chromosoma, 76, 123-150.

LOPEZ-FER NANDEZ, C., RUFAS, J. S. AND GOSALVEZ: J. 1982. Non-random segregation during anaphase II in an individual of Arcyptera tornosi (Bol.) (Orthoptera) heterozygous for three supernumerary heterochromatic segments. Genetica, 60, 37-39.

PASCUAL, F. 1978. Estudio preliminar de los Ortópteros de Sierra Nevada. I. Introducción general e inventario de especies. Bol. Asoc. Esp. Entom., 1, 163-175.

ROCCHI, A. 1982. On the heterogeneity of heterochromatin. Caryologia, 35, 169-189.

SANTOS, J. L. AND GIRALDEZ, R. 1978. The effect of C-heterochromatin in chiasma terminalisation in Chorthippus biguttulus L. (Acrididae, Orthoptera). Chromosoma, 70, 59-66.

SANTOS, J. L. AND GIRALDEZ, R. 1982. C-heterochromatin polymorphism and variation in chiasma localization in Euchorthippus pulvinatus gallicus (Acrididae, Ortoptera). Chromosoma, 85, 507-518.

SHAW, D. D. 1970. The supernumerary segment system of Stethophyma. I. Structural basis. Chromosoma, 30, 326-343.

WEbB, G. C., White, M. J. D., CONTRERAS, N. AND CheneY, J. 1978. Cytogenetics of the parthenogenetic grasshopper Warramaba (formerly Moraba) virgo and its bisexual relatives. IV. Chromosome banding studies. Chromosoma, 67, 309-339.

WESTERMAN, M. 1969. Parallel polymorphism for supernumerary segments in Chorthippus parallelus (Zetterstedt). II. French populations. Chromosoma, 26, 7-21.

WESTERMAN, M. 1970. Parallel polymorphism for supernumerary segments in Chorthippus parallelus. V. A new polymorphism in Europe. Heredity, 25, 662-667.

WHITE, M. J. D. 1973. Animal Cytology and Evolution. Third edition. Cambridge University Press. 